\title{
How Much Does Education Matter and Why? The Effects of Education on Socio-Economic Outcomes among School-Leavers in the Netherlands
}

Citation for published version (APA):

van der Velden, R. K. W., \& Wolbers, M. H. J. (2007). How Much Does Education Matter and Why? The Effects of Education on Socio-Economic Outcomes among School-Leavers in the Netherlands. European Sociological Review, 23(1), 65-80. https://doi.org/10.1093/esr/jcl020

Document status and date:

Published: 01/01/2007

DOI:

10.1093/esr/jcl020

Document Version:

Publisher's PDF, also known as Version of record

Please check the document version of this publication:

- A submitted manuscript is the version of the article upon submission and before peer-review. There can be important differences between the submitted version and the official published version of record.

People interested in the research are advised to contact the author for the final version of the publication, or visit the DOI to the publisher's website.

- The final author version and the galley proof are versions of the publication after peer review.

- The final published version features the final layout of the paper including the volume, issue and page numbers.

Link to publication

\footnotetext{
General rights rights.

- You may freely distribute the URL identifying the publication in the public portal. please follow below link for the End User Agreement:

www.umlib.nl/taverne-license

Take down policy

If you believe that this document breaches copyright please contact us at:

repository@maastrichtuniversity.nl

providing details and we will investigate your claim.
}

Copyright and moral rights for the publications made accessible in the public portal are retained by the authors and/or other copyright owners and it is a condition of accessing publications that users recognise and abide by the legal requirements associated with these

- Users may download and print one copy of any publication from the public portal for the purpose of private study or research.

- You may not further distribute the material or use it for any profit-making activity or commercial gain

If the publication is distributed under the terms of Article 25fa of the Dutch Copyright Act, indicated by the "Taverne" license above, 


\title{
How Much Does Education Matter and Why?
}

\section{The Effects of Education on Socio-economic Outcomes among School-leavers in the Netherlands}

\author{
Rolf K. W. van der Velden and Maarten H. J. Wolbers
}

This article explores the total (measured and unmeasured) impact of education on some of the main socio-economic outcomes (that is, employment opportunities, job security and wages) among school-leavers who finished upper secondary or tertiary education in the Netherlands. The empirical analysis shows that the effects of education are typically underestimated in labour market research. Education has a large impact on all outcomes under investigation. Apart from level of education, the selectivity of the study programme turns out to affect socio-economic outcomes, although the effects of the latter educational characteristic are only significant in the private sector. Differences between schools do not have an impact on wages and job security, but they do to some extent affect employment opportunities.

\section{Introduction}

This article focuses on the effects of education on various socio-economic outcomes among schoolleavers who finished upper secondary or tertiary education in the Netherlands. These different socioeconomic outcomes reflect some of the main dimensions of the labour market position of school-leavers: employment opportunities, job security, and wages. Different theories predict different effects of education on these outcomes. The effects of education may be related to two different sources. On the one hand, it may relate to having followed a specific field of study (for instance, sociology) at a particular level of education (for instance, master level). From now on, we refer to this as study programme effects. On the other hand, it may relate to having attended a specific educational institution (for instance, university X). From now on, we refer to that as school effects.

A lot of sociological research has found clear and undisputed effects of the level of the study programme on employment opportunities, occupational status, and earnings (for recent contributions see Shavit and Müller, 1998; Kerckhoff et al., 2001; Müller and Gangl, 2003). Moreover, study programme effects have been demonstrated regarding differences between vocational and academic programmes (Bishop, 1989) and differences between fields of study (van de Werfhorst and Kraaykamp, 2001). School effects have been established, for instance, with respect to the reputation of the college (Wilson and Smyth-Lovin, 1983), the social network of the college (Rosenbaum et al., 1999), and the quality of the school (Dolton and Vignoles, 2000).

A drawback of this research is that it usually focuses on the effects of specific characteristics and rarely takes 
all possible effects of education into account. This may result in an underestimation of the actual effects of education, because the models in question only reflect the effect of some measured characteristics, such as the level of education. Even in the case where other characteristics of education are taken into account, the conducted analysis only reflects the effects of the measured characteristics, which still leaves the possibility that there are other (unmeasured) characteristics that matter.

At the same time, however, the effects of education may well be overestimated. Part of what seems to be an effect of education is actually spurious, because students are differentially selected into study programmes. Without adequate control for student composition, the effects of study programmes may be overestimated. The same holds for the effects of schools. For example, part of the school differences may be related to the fact that schools are located in different regions, which in turn face different labour market situations. Without adequate control for these regional effects, the school effects may well be overestimated. We can see a similar point of view in the school effectiveness research (Scheerens and Bosker, 1997), where school effects are defined as the added value of the school, controlling for input characteristics. The net effects of schools (that is, the effects after controlling for input characteristics) are usually found to be much smaller than the gross effects.

This means that the essential question here about the extent to which education affects socio-economic outcomes is still very much open for discussion. Multilevel analysis offers a solution for the underestimation problem, since it enables adequate estimation of the total (measured and unmeasured) effect of education in a hierarchical data structure (Snijders and Bosker, 1999). By controlling for relevant input characteristics of the students and characteristics in the school environment, we also try to address the overestimation problem. In this article, we therefore use this multivariate regression method to estimate the total (net) effect of education on socio-economic outcomes among school-leavers who finished upper secondary and tertiary education in the Netherlands and to decompose this effect into differences between study programmes and differences between schools. ${ }^{1}$

A second unresolved issue is the explanation of the effects of education. Human capital theory basically argues that education is crucial, because it imparts knowledge and skills that directly affect the worker's labour productivity. Job competition theory stipulates that education is important, because it selects on general learning abilities, which in turn determine the individual's training costs for acquiring job-specific skills. In this article, we adopt a theoretical model that combines these two perspectives into one model, the training costs model (Glebbeek, 1988). We elaborate that both theories predict different outcomes for different components of this model. Moreover, we hypothesize that there are differences among labour market segments in the mechanisms that create the allocation and selection process, and that these differences are the result of the nature of the employment relationship in different segments (Sørensen, 1983).

\section{Description of Dutch Education System}

The Dutch education system is regarded as being highly stratified (both vertical and horizontal) and highly standardized (Shavit and Müller, 1998). Stratification refers to the extent and form of tracking at the level of secondary education. In highly stratified education systems, students are selected into separate tracks early in the educational career with no or few possibilities to switch between these tracks. Standardization refers to the degree to which the quality of education meets the same standards nationwide (with regard to teacher training, school budgets, curricula, and uniformity of examination or certification terms). As can be seen from Figure 1, stratification appears relatively early in the educational career of Dutch students. At the start of secondary education (at age 12), students are allocated to four major tracks that differ in both length and level (first-phase secondary education). This allocation is based on a national school performance test and the advice of the teacher from primary education. None of these four tracks is considered to be proper final levels of education, although some students leave education after completion (or even without) of one of these tracks. However, a large majority of the degree takers go on to further education. Completion of the highest of the four tracks (VWO) gives access to the master programmes at the universities (WO). The next highest track (HAVO) gives access to the bachelor programmes in colleges of higher vocational education (HBO). The two lowest tracks (VBO and MAVO) give access to the school-based vocational programmes in (short) senior secondary vocational education $((\mathrm{K}) \mathrm{MBO})$ or to the dual system of apprenticeship training. Within these levels of education, students are (within some limitations) free to choose between the 


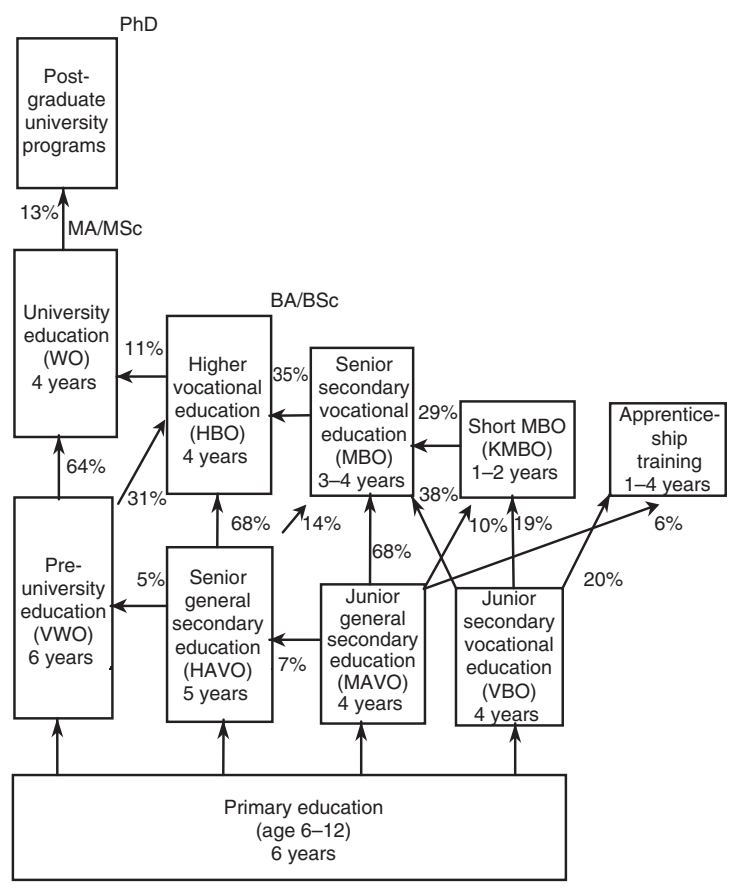

Figure 1 The Dutch education system. Note: The percentages show outflow rates to continuing education. For example, 64 per cent of the degree takers from WWO continue in WO and 31 per cent go to HBO. The rest $(100-64-31=5$ per cent) does not go to further education, but enters the labour market. Source: ROA school-leaver survey 1998

available study programmes. As indicated, horizontal stratification is quite substantial in the Dutch education system and students can choose between some hundreds of study programmes within each level (for instance, master level sociology, bachelor level business administration, senior secondary vocational education level nurse training, etc.). Most schools offer a broad range of study programmes and there is no relation between school quality and the set of study programmes offered. In the context of this article, this horizontal differentiation is especially relevant for studying the effects of education. If education is crucial in imparting knowledge and skills, then this should not only be reflected by different socio-economic outcomes between levels of education, but also by differences between study programmes within the same level. Due to the high level of standardization in the Dutch education system (mainly through national agreed curricula), the content of these programmes is quite similar across schools. Nevertheless, schools differ in educational outcomes (such as the average school performance of their students). Controlling for differences in input characteristics (such as social background and ability), these between-school differences in educational outcomes in the Netherlands have been estimated to be some 5-15 per cent for primary and secondary education (Scheerens and Bosker, 1997) which parallels differences found elsewhere (Mortimore et al., 1988). It can therefore be assumed that schools may also differ in socio-economic outcomes. An earlier Dutch study indeed seems to point out that there are school differences in socio-economic outcomes (Bosker et al., 2001). However, these results were restricted to colleges of higher vocational education. This article broadens the focus to the full range of (school-based) study programmes in the Dutch system of upper secondary and tertiary education that represent around 85 per cent of the regular outflow to the labour market.

\section{How Much Does Education Matter? Statistical Modelling Issues}

Labour market research typically underestimates the effects of education on socio-economic outcomes, 
since it only shows the impact of measured characteristics such as the level of education. To assess the total effect of education one should take into account both measured and unmeasured effects of education. In a conventional regression model, taking account of all systematic differences between the study programmes and between the schools would require to include a full set of dummy variables representing all study programmes and all schools. However, such a model does not take into account the fact that measurement errors within study programmes or within schools may be correlated. A more adequate and parsimonious way to analyse such data is by applying multilevel analysis. The basic idea of this multivariate regression method is that data with a nested structure, are not adequately represented by the probabilistic model of multiple regression analysis, but should be analysed in a hierarchical linear model or random coefficient model (Snijders and Bosker, 1999).

Let $\mathrm{Y}$ denote some socio-economic outcome, $\mathrm{X}$ is a vector of characteristics of individual $i, S$ is a vector of characteristics of school $\mathrm{s}$ and $\mathrm{P}$ is a vector of characteristics of study programme p. R, U and V are random error terms at the individual, school, and study programme level, respectively. Then the specified model is:

$$
\begin{aligned}
\mathrm{Y}_{\text {isp }}= & a_{1}+a_{2}(\mathrm{X})_{\text {isp }}+a_{3}(\mathrm{~S})_{\mathrm{sp}}+a_{4}(\mathrm{P})_{\mathrm{p}}+\mathrm{R}_{\text {isp }} \\
& +\mathrm{U}_{\mathrm{sp}}+\mathrm{V}_{\mathrm{p}}
\end{aligned}
$$

This model has a hierarchical structure in which individuals are nested in school-study programme combinations (for instance, master level sociology programme at university $\mathrm{X}$ ) and these are, in turn, nested in study programmes (in this example, the master level sociology programme). Given the high level of standardization in the Dutch education system, the particular study programme that someone has followed is considered to be more important in affecting socio-economic outcomes than the particular school that has been attended. This is the reason why we modelled study programmes as the highest level. This way we can easily assess the total variation due to systematic differences between study programmes. Note that, in order to maintain the hierarchical structure, the intermediate level has to be defined as a particular school-study programme combination rather than a school as a whole. In other words, each study programme offered in a particular school is considered as a separate unit at this level. This is not a problem and gives us the opportunity to model study programme-specific effectiveness of schools.
Stated differently, schools may not be good in all programmes they offer, but only in some (for instance, the quality of study programme $p_{1}$ might be the highest in school $s_{1}$, whereas the quality of study programme $\mathrm{p}_{2}$ might be the highest in school $\mathrm{s}_{2}$ ). If we would look at the general effectiveness of schools, the school effect may not entirely be picked up, as the various differences in effectiveness of study programmes within schools could cancel each other out. The proposed way of modelling actually allows for the greatest possibility of detecting school effects.

The usual way to proceed is to start with the calculation of a baseline model where only the intercept is estimated. This model gives an indication of the amount of variation that can be attributed to the different levels (individuals, schools, study programmes). However, as indicated earlier, these results cannot directly be interpreted as effects that are due to the particular study programme followed or effects of the school attended. Part of the systematic variation between study programmes and schools is due to differential selection of students into study programmes and schools or to other factors that are unrelated to characteristics of the study programme and the school. Without adequate statistical control for this, we probably overestimate the 'true' effects of education. Therefore, we first estimate a model in which variables have been included that try to control for these composition effects, allowing us to get closer to the 'true' effects of education.

The following hypotheses are formulated regarding the question on how much education matters:

Hypothesis 1: Given the highly standardized and highly stratified education system in the Netherlands, we expect small differences between schools (that is, schools ${ }^{*}$ study programmes) and large differences between study programmes in socio-economic outcomes.

Hypothesis 2: We expect that the (small) differences between schools (that is, schools ${ }^{*}$ study programmes) are larger in the case of employment opportunities and job security than in the case of wages.

The latter hypothesis is related to the fact that employment opportunities and job security may vary between schools offering different support to their graduates in helping to find a (permanent) job (Rosenbaum et al., 1990), while wages are often set in national collective agreements leading to the same starting salary for two school-leavers who finished the same occupation-specific study programme at different schools. 


\section{Why Does Education Matter? Theoretical Issues}

According to human capital theory (Becker, 1964), people acquire skills in education that make them directly productive for jobs. By investing in education, they improve their labour productivity. As labour productivity is mainly determined by characteristics of the worker, investments in education increase their future wages. Because of wage competition, different investments in education lead to differences in wage level, but not in job opportunities as such. This view has been challenged in the job competition theory from Thurow (1975). This theory assumes that labour productivity is determined by job characteristics instead of worker characteristics. It also assumes that work-related skills are mainly acquired on-the-job and not in education. Education in this view serves as a 'screening device' or 'signal' (Spence, 1973), indicating general characteristics such as learning abilities, motivation and perseverance that enable school-leavers to acquire new job skills. Whether or not these generic skills are actually developed in education is not important. What matters is that these generic skills are important predictors of the training costs, and employers will therefore use educational credentials to screen job applicants and put them in an imaginary labour queue (Thurow, 1975). Education is one of the determinants of the relative position in this queue, and thus affects not only wages (determined by the job individuals get), but also job opportunities (those with the least education are always placed behind). ${ }^{2}$

Although it is theoretically useful to distinguish the different mechanisms through which employers sort and select employees, in reality it is very unlikely that these selection processes follow a pure human capital model or a pure job competition model. In many cases, elements of both types of selection can be found and it is probably more fruitful to specify the conditions under which one or the other mechanism prevails than to claim that only one mechanism explains all. A common element of both theories is that they assume that employers act rationally and choose workers with the highest expected productivity. Glebbeek (1988) has used this similarity between human capital theory and job competition theory to develop a model in which the two perspectives are combined: the training costs model. Following Thurow (1975), he assumes that workers are primarily selected on the basis of their expected training costs. He also assumes that employers cannot assess these expected training costs directly, but have to infer them from the average expected training costs of school-leavers from a specific study programme. Unlike Thurow, he allows for the possibility that productive skills can be acquired in education. In his view, the expected training costs of school-leavers from a certain study programme are determined by three components. The first component concerns the relative degree to which the study programme in question provides the required skills. This coincides largely with the occupational specificity of a study programme. The more specific a study programme prepares for a particular job, the less additional training school-leavers need. From this, it follows that school-leavers from more general study programmes will require more on-thejob training in order to perform adequately on the work floor than those who have completed an occupation-specific study programme, provided that the latter end up working in a matching job. The second component relates to the selectivity of the study programme. Education does not produce a homogeneous good. Even school-leavers from the same study programme may still differ widely in quality. For the employer, this poses a problem because the overperformance of one graduate does not simply compensate the underperformance of another (van der Velden, 2001). Study programmes differ in the risk they offer that graduates will pass the exam without having a minimum level of skills. If we assume that employers are able to recognize such differences in selectivity, then this may have an impact on their recruitment behaviour, and hence on the labour market position of school-leavers. Highly selective study programmes offer low risks and vice versa. The third component relates to the effort that employers have to make to 'bridge' any existing skill deficiencies of individuals, either at the moment of labour market entry or in the future career. This component is linked in particular to the school-leaver's general learning capabilities. It is assumed that the greater the individual learning capabilities are, the lower the required training costs.

In the empirical analysis of this article, we include a measure for all three components. The first component is indicated by the specificity of the study programme, the second component by the selectivity of the study programme, and the third by the level of education. Although the training costs model can be thought of as comprising both elements of human capital and job competition theory, it is clear that the original theories would predict different outcomes for the separate components. Human capital theory predicts strong effects of level of education on wages (and probably other related terms of employment such 
as the permanency of the employment contract), but no effect-in a perfect market situation at least-on employment opportunities. Job competition theory, however, predicts strong effects of level of education on all socio-economic outcomes, not only wages. The component of selectivity is clearly more related to job competition theory than human capital theory. The former theory predicts positive effects of selectivity on job opportunities as well as on wages and other terms of employment. Finally, the component of specificity is more related to human capital theory. This theory predicts a positive effect of specificity on wages (and other terms of employment), as a result of the enhancing effect of direct labour productivity. However, the effect of specificity on employment opportunities is ambiguous. On the one hand, specificity leads to clear signals to employers about the acquired skills, thus improving the transparency and lowering the search time. On the other hand, specificity leads to increased job search duration as supply and demand need more time to meet and match.

As outlined earlier, it is not very fruitful to formulate general hypotheses whether selection mechanisms follow human capital theory or job competition theory. It is more interesting to show that under certain conditions one or the other mechanism prevails. It is clear that the mode of selection is tightly interwoven with the partition of the labour market into segments and related differences in the nature of the employment relationship that exist between segments (Sørensen, 1983). In openemployment relationships, which predominate in profit-maximizing firms, employees are exposed to competition from other workers on the basis of their productive capacity and, therefore, human capital theory applies. In closed-employment relationships, characterized by strong internal labour markets and large bureaucratic organizations where productivity is less relevant, employees are protected from wage competition and access to jobs (new entries or promotions) can take place only when there is a vacancy. This job access is determined by a ranking of job candidates, as assumed by job competition theory. Although the distinction between these two types of employment relationships does not coincide completely with a distinction between the public and private sector, we use the latter to formulate our hypotheses. ${ }^{3}$ It is assumed that openemployment relationships particularly emerge in the private sector, whereas closed-employment relations prevail in the public sector. Note, by the way, that these hypotheses can only be formulated for the employed labour force and thus relate to job security and wages only.

Hypothesis 3: We expect that the effects of level of education on socio-economic outcomes are present both in the public and in the private sector.

Hypothesis 4: We expect that the effects of the selectivity of the study programme on socio-economic outcomes are larger in the public sector than in the private sector.

Hypothesis 5: We expect that the effects of the specificity of the study programme on socio-economic outcomes are larger in the private sector than in the public sector.

\section{Data and Variables}

\section{Data}

For the empirical analysis, we use data from the annual school-leaver survey conducted by the Research Centre for Education and the Labour Market (ROA) of Maastricht University. This cross-sectional survey maps the transition from school to work for schoolleavers in the Netherlands approximately one-and-ahalf years after leaving education. We analyse the data collected in 1998, thus covering school-leavers from the school year 1996-1997. The survey covers schoolleavers with a qualification from any type of secondary or tertiary education. They received a mail questionnaire that contained questions about employment opportunities [unemployment (spells), job search duration], contract type (temporary, part-time contract), job characteristics (wage, job level, job requirements), and employer characteristics (sector, firm size).

The school-leaver survey plays an important role in the Dutch system of educational quality assurance. That is the main reason why the survey covers a large part of the total outflow of education. The participation rate is 100 per cent among universities, 85 per cent among colleges of higher vocational education, 40 per cent among schools for senior secondary vocational education and 10 per cent among schools for general secondary education and junior secondary vocational education. The sample from the 1998 data collection is found to be representative for the total outflow of secondary and tertiary education. Response rates varied a lot between levels of education: from 39 per cent for short senior secondary vocational education (KMBO) to 66 per cent for pre-university education (VWO). These response rates are considered to be quite good for a mail questionnaire in the Netherlands. Moreover, an additional survey among some 1,300 non-respondents showed that the response 
was not selective with respect to a number of socioeconomic outcomes. Despite the differences in response rates, this holds for each level of education. For the multivariate analysis that is applied, we use the un-weighted data set. For a more detailed description of the methodology used in the survey, we refer to Huijgen and Wolbers (1999).

For the present analysis, we select school-leavers with a qualification from short senior secondary vocational education (KMBO), senior secondary vocational education $(\mathrm{MBO})$, higher vocational education (HBO) or university education (WO). The different qualifications can be considered as successive in level. Within this sample, we select those respondents who belonged to the labour force at the moment of the survey. Moreover, to exclude respondents that have already gained work experience before leaving education, we select on age within each level of education: KMBO (maximum of 23 years at the moment of interview), MBO (maximum 25 years), HBO (maximum 28 years), and WO (maximum 30 years). These selections result in an analytic sample of maximally 20,112 school-leavers, maximally 993 schools* $^{*}$ study programmes, and 215 study programmes. The data are grouped as a three-level hierarchy with school-leavers nested in school-study programme combinations and school-study programme combinations nested in study programmes.

\section{Dependent Variables}

We analyse three socio-economic outcomes that reflect some of the main dimensions of the labour market position of school-leavers. The first dependent variable is the likelihood of being employed as against being unemployed and actively seeking work. The second one-restricted to those who are employed-looks at the likelihood of being employed in a permanent job rather than being employed on a temporary basis. We define permanent employment to include jobs with a contract of unlimited duration and jobs with the prospect of permanent employment. The third one is the natural log of the gross hourly wages, originally measured in guilders but translated into euro according to the official exchange rate of 2.21371. Hourly wages less than 1 euro have been recoded to 1 euro before logging them. In the calculation of the hourly wages, we applied a correction to take account of the system of minimum youth wages. In the Netherlands, for those between 16 and 23 years old, there is a system of minimum youth wages that increases progressively with age, until it reaches the minimum wage for 23 years and older. The wages of all school-leavers aged between 16 and 22 years are more or less affected in the same way by this minimum youth wage system. So, we multiplied the wages of those under the age of 23 with a correction factor that is the inverse of the ratio of the minimum wage for that school-leaver's age and the minimum wage for 23 years and older.

\section{Independent Variables}

The effects of education may be overestimated if one does not control properly for input characteristics and other variables that may obscure the net effects of study programmes and schools. At the school-leaver level, we therefore include four relevant covariates. Sex is a dummy variable distinguishing men and women. Social background is indicated by the parental level of education, measured as the average years of schooling of both parents. The assigned scores are as follows: primary education 6 years, VBO 10 years, MAVO 11 years, HAVO 13 years, MBO 14 years, VWO 15 years, HBO 17 years, and WO 19 years (see van der Velden and Smoorenburg (1999) for further details). The information on the parental level of education is based on questions to the school-leavers. In the case of a missing value of one of the parents, the parental level of education is equal to the level of education of the other parent. Ethnicity is a dummy variable distinguishing between ethnic minorities and Dutch natives. A person of ethnic minority is either someone who was born abroad and of whom at least one of the parents was born abroad, or someone of whom both parents were born abroad. Countries that are classified as abroad are listed in the Dutch Act for Stimulation of Participation of Ethnic Minorities in the Labour Market (SAMEN). The level of first-phase secondary education indicates the highest track followed in the first phase of secondary education before entering higher education ( $\mathrm{HBO}$ and $\mathrm{WO}$ ) or (short) intermediate vocational education $((\mathrm{K}) \mathrm{MBO})$. It distinguishes pre-university education (VWO), senior general secondary education (HAVO) and junior general secondary education/junior secondary vocational education (MAVO/VBO). These tracks have differential possibilities for continuing education (as has been shown in Figure 1). However, students do not necessarily choose the highest form of further education possible (de Graaf and Wolbers, 2003). This variable can be regarded as a good predictor of the cognitive differences between students when entering the different study programmes in continuing education. ${ }^{4}$ 
At the school-study programme combination level, we include the unemployment rate in the region where the school-leavers attended school (CBS, 2002). A total of 18 regions ('RBA-areas') are distinguished. This variable is included to control for between-school variation that is due to regional rather than schoolspecific characteristics.

To measure the three components of the training costs model, the following educational characteristics are distinguished. The first concerns the level of education, measured in years of schooling. The following values are assigned: short senior secondary vocational education (KMBO) 12 years, senior secondary vocational education (MBO) 14 years, higher vocational education (HBO) 17 years and university education (WO) 19 years. This implies that this characteristic is invariant between study programmes within an educational level. The second educational characteristic refers to the selectivity of the study programme. Even within a given level of education, there is still considerable variation in the quality of the study programmes offered. To estimate this quality variation, we calculated for each study programme the percentage of students having the highest track of first-phase secondary education (that is, VWO for those with a study programme in WO or $\mathrm{HBO}$, HAVO for those with a study programme in $\mathrm{MBO}$ and MAVO or HAVO for those with a study programme in $\mathrm{KMBO}$ ). Within each educational level these indicators were then standardized. This means that the measure can be compared across levels, since it gives a ranking of study programmes within each level of education. The third characteristic is the specificity of the study programme. This refers to the relative degree to which the study programme in question provides the required skills. If school-leavers from a particular study programme are largely concentrated in one occupation, then this study programme is considered to be highly specific. If, on the other hand, school-leavers from a particular study programme are dispersed across a great number of occupations, then it is considered to be highly generic. The specificity is measured by calculating a GiniHirschman coefficient for the range of occupations for each study programme. The coefficient can take values between 0 (all school-leavers are located in one occupation) and 100 (all school-leavers are equally distributed across all possible occupations). A high value therefore represents low specificity. The coefficients were estimated using the Dutch Labour Force Surveys of 1995 and 1996. Since we are interested in the specificity of study programmes, the reverse sign of the coefficients is used, which means that a high value indicates a high degree of specificity.

Finally, to specify differences in the effects of the three educational characteristics between the public and the private sector, we include-in addition to the main effect of sector-interaction terms between the sector variable and the three measures for education.

A statistical description of all variables is presented in Table 1.

\section{Models}

For the analysis of being employed, three models have been estimated. Model 0 is the baseline model containing the intercept only. Model 1 includes all covariates measured at the level of school-leavers and the level of school-study programme combinations. Both models together indicate how much education matters by decomposing the total variation in employment opportunities among school-leavers into the three variance components (Model 0) and statistically controlling for crucial variables to obtain an adequate estimate of the net variation between study programmes and between school-study programme combinations (Model 1). In Model 2, the three educational characteristics are added. This model answers the theoretical question of why education matters. For the analysis of being employed in a permanent job and the analysis of gross hourly wages, four models have been estimated. Models 1, 2, and 3 are comparable with the analysis of being employed. In Model 4, we add a dummy variable that distinguishes the private from the public sector and interaction terms between this variable and the three educational characteristics.

One particular issue to be raised is the calculation of variance components in the case of logistic multilevel analysis. To calculate the explained variance in the estimated logistic 3-level models (that is, when analysing the likelihood of being employed and the likelihood of being employed in a permanent job), we follow the method proposed by Snijders and Bosker (1999: 225-227). The explained variance is calculated as the observed variance of the linear predictor for $\mathrm{Y}_{\text {isp }}$ using the estimated coefficients of the model. The total variance is then calculated as the sum of this explained variance plus the residual variance at level one (fixed at 1 due to the binary character of the dependent variable), level two, and level three. However, note that 'such values are known for single-level logistic regression to be usually considerably smaller than the OLS $R^{2}$ values obtained for predicting continuous outcomes' (Snijders and Bosker, 1999: 226). 
Table 1 Statistical description of the variables used in the multilevel analysis (maximally 20,112 school-leavers within maximally 993 schools*study programmes within 215 study programmes)

\begin{tabular}{|c|c|c|c|}
\hline & Percentage & Mean & SD \\
\hline \multicolumn{4}{|l|}{ Independent variables } \\
\hline \multicolumn{4}{|l|}{ Level 1 variables } \\
\hline Female (versus male) & 55 & & \\
\hline Ethnic minority (versus native Dutch) & 3 & & \\
\hline First-phase secondary education HAVO (versus VBO/MAVO) & 47 & & \\
\hline First-phase secondary education VWO (versus VBO/MAVO) & 16 & & \\
\hline Parental level of education $(6-19)$ & & 12.04 & 2.99 \\
\hline Private sector (versus public sector) & 68 & & \\
\hline \multicolumn{4}{|l|}{ Level 2 variable } \\
\hline Regional unemployment rate (3-8) & & 5.10 & 1.13 \\
\hline \multicolumn{4}{|l|}{ Level 3 variables } \\
\hline Level of education (12-19) & & 16.89 & 2.11 \\
\hline Selectivity of study programme $(-0.59-0.99)$ & & -0.02 & 0.21 \\
\hline Specificity of study programme $(-17.85-1.15)$ & & -9.43 & 5.08 \\
\hline \multicolumn{4}{|l|}{ Dependent variables } \\
\hline Being employed (versus unemployed) & 97 & & \\
\hline Being employed in a permanent job (versus temporary job) & 85 & & \\
\hline Log gross hourly wages $(0-5.29)$ & & 2.22 & 0.33 \\
\hline
\end{tabular}

Source: ROA school-leaver survey 1998.

\section{Results}

\section{Being Employed}

Table 2 displays the results of a logistic 3-level random intercept model analysing the likelihood of being employed. Model 0 shows significant variation in the likelihood of being employed between study programmes. Although there is also variation between school-study programme combinations, this variation is not significantly different from zero. The variation between study programmes is larger than the variation between school-study programme combinations. The gross variation between study programmes is 26.6 per cent of the estimated total variation, while the variation between school-study programme combinations is only 7.9 per cent, indicating that the study programme followed affects the likelihood of having a job much more than the specific school where the study programme was followed. This is in accordance with Hypothesis 1. As the variance at the level of school-leavers is fixed at 1 , the residual variance components cannot be directly compared across the different models. We therefore look at the changes in the percentages rather than the changes in the variances itself. After introduction of the covariates in Model 1, almost 4 per cent of the estimated total variance can be explained. Most of this explained variance is related to a decrease in residual variance at the level of study programmes. The residual variance at the level of study programmes drops from 26.6 to 22.8 per cent, which implies that around one-seventh $((1-22.8 / 26.6) \times 100)$ of the gross variance at this level can be attributed to the included covariates. The residual variance at the level of school-study programme combinations hardly changes (or, in fact, increases slightly from 7.9 to 9.0 per cent), indicating that no variation between schoolstudy programme combinations can be ascribed to the covariates. The total net effect of education (that is, the net effect of having followed a particular study programme at a particular school) is estimated to explain a maximum of one-third $(9.0+22.8$ per cent $)$ of all differences between school-leavers in the likelihood of being employed. Introduction of other (omitted) covariates could possibly lower this percentage.

In Model 2, the educational characteristics are added, which leads to only a very small decrease in the residual variance at the level of study programmes (from 22.8 to 20.4 per cent) and no change in residual variance at the level of school-study programme combinations. This implies that the net variation between study programmes and between school-study programme combinations can hardly be ascribed to any of the included educational characteristics. 
Table 2 Results of logistic 3-level analysis of being employed: logit effects (20,112 school-leavers within 993 schools*study programmes within 215 study programmes)

Model $0 \quad$ Model $1 \quad$ Model 2

\begin{tabular}{|c|c|c|c|}
\hline Intercept & $3.463^{\star *}$ & $4.745^{\star *}$ & $5.233^{\star *}$ \\
\hline \multicolumn{4}{|l|}{ Level 1 variables } \\
\hline Female (versus male) & & -0.169 & -0.176 \\
\hline Ethnic minority (versus native Dutch) & & $-0.741^{\star *}$ & $-0.751^{\star *}$ \\
\hline First-phase secondary education HAVO (versus VBO/MAVO) & & -0.119 & -0.074 \\
\hline First-phase secondary education VWO (versus VBO/MAVO) & & -0.018 & -0.041 \\
\hline Parental level of education & & $-0.043^{\star *}$ & $-0.041^{\star *}$ \\
\hline \multicolumn{4}{|l|}{ Level 2 variable } \\
\hline Regional unemployment rate & & $-0.109^{\star \star}$ & $-0.115^{\star \star}$ \\
\hline \multicolumn{4}{|l|}{ Level 3 variables } \\
\hline Level of education & & & -0.017 \\
\hline Selectivity of study programme & & & $0.878^{\star *}$ \\
\hline Specificity of study programme & & & 0.022 \\
\hline \multicolumn{4}{|l|}{ Variance components (percentages) } \\
\hline Residual variance level 1: school-leavers & $1.000(65.5)$ & $1.000(64.4)$ & $1.000(63.5)$ \\
\hline Residual variance level 2: schools ${ }^{\star}$ study programmes & $0.121(7.9)$ & $0.140(9.0)$ & $0.142(9.0)$ \\
\hline Residual variance level 3: study programmes & $0.406^{\star \star}(26.6)$ & $0.354^{\star \star}(22.8)$ & $0.322^{\star \star}(20.4)$ \\
\hline Explained variance & $0.000(0.0)$ & $0.058(3.7)$ & $0.112(7.1)$ \\
\hline Total variance & $1.527(100.0)$ & $1.552(100.0)$ & $1.576(100.0)$ \\
\hline
\end{tabular}

Significance: $* P<0.05 ; * * P<0.01$ (two-tailed).

Source: ROA school-leaver survey 1998.

There is only an effect of the selectivity of the study programme. If the selectivity is increased with one point, then the odds of being employed increase with $141\left(\mathrm{e}^{0.878}=2.406\right)$ per cent.

\section{Being Employed in a Permanent Job}

Table 3 presents the results with respect to the likelihood of being employed in a permanent job. If we look at the estimates of the variance components in Model 0 , we can conclude that there is significant variation only at the level of study programmes: 27.2 per cent of the total variance. The variance at the level of schools*study programmes is 0.1 per cent. These results support Hypothesis 1. Introduction of the covariates in Model 1 causes a drop in the variance at the level of study programmes from 27.2 to 23.2 per cent. Model 1 indicates that the total net effect of education is 23.5 per cent $(=0.3+23.2$ per cent $)$ of the total variation. In other words, a maximum of onequarter of the differences between school-leavers in the likelihood of being employed in a permanent job can be attributed to the specific programme they have followed (and the specific school they have attended).

Introducing the three educational characteristics in Model 2 explains only a part of the differences between study programmes and school-study programme combinations as found in Model 1. The residual variance at the level of study programmes is now 21.2 per cent. This means that less than 10 per cent of the net variation between study programmes can be ascribed to the modelled educational characteristics. Only the level of education has a significant effect on the likelihood of being employed in a permanent job. Each additional year of schooling increases the odds with 11 per cent $\left(e^{0.101}=1.106\right)$.

In Model 3 the effects of the three educational characteristics are estimated separately for the private and public sector. ${ }^{5}$ In this model, the residual variance at the level of study programmes further decreases to 19.9 per cent. The main effect of level of education is no longer significant, while the interaction term with the private sector is significant. In other words, Hypothesis 3 is only partly confirmed. There is no effect of level of education in the public sector, but there is a strong effect of education in the private sector. The latter effect is $0.134(0.061+0.073)$. In addition, the interaction terms reveal that the effect of the selectivity of the study programme is larger in the private sector as well, although in neither the private nor the public sector this effect differs statistically from the value zero. This finding contradicts Hypothesis 4, where we expected the opposite to hold true. Finally, the results show no difference in the 
Table 3 Results of 3-level analysis of being employed in a permanent job: logit effects (18,770 school-leavers within 982 schools*study programmes within 215 study programmes)

\section{Model $0 \quad$ Model $1 \quad$ Model $2 \quad$ Model 3}

\begin{tabular}{|c|c|c|c|c|}
\hline Intercept & $1.662^{\star *}$ & $2.266^{\star \star}$ & 0.595 & $1.198^{\star}$ \\
\hline \multicolumn{5}{|l|}{ Level 1 variables } \\
\hline Female (versus male) & & $-0.283^{\star *}$ & $-0.281^{\star *}$ & $-0.269^{\star *}$ \\
\hline Ethnic minority (versus native Dutch) & & $-0.358^{\star \star}$ & $-0.354^{\star \star}$ & $-0.348^{\star \star}$ \\
\hline $\begin{array}{l}\text { First-phase secondary education HAVO } \\
\text { (versus } \mathrm{VBO} / \mathrm{MAVO} \text { ) }\end{array}$ & & 0.021 & -0.065 & -0.062 \\
\hline $\begin{array}{l}\text { First-phase secondary education VWO } \\
\text { (versus } \mathrm{VBO} / \mathrm{MAVO} \text { ) }\end{array}$ & & 0.123 & 0.056 & 0.057 \\
\hline Parental level of education & & $-0.019^{\star *}$ & $-0.021^{\star *}$ & $-0.021^{\star *}$ \\
\hline Private sector (versus public sector) & & & & $-1.115^{\star}$ \\
\hline \multicolumn{5}{|l|}{ Level 2 variable } \\
\hline Regional unemployment rate & & $-0.045^{\star}$ & $-0.040^{\star}$ & $-0.039^{\star}$ \\
\hline \multicolumn{5}{|l|}{ Level 3 variables } \\
\hline Level of education & & & $0.101^{* *}$ & 0.061 \\
\hline Selectivity of study programme & & & 0.234 & -0.362 \\
\hline Specificity of study programme & & & -0.006 & 0.013 \\
\hline \multicolumn{5}{|l|}{ Interactions } \\
\hline $\begin{array}{l}\text { Level of education* }{ }^{*} \text { private sector } \\
\quad \text { (versus public sector) }\end{array}$ & & & & $0.073^{* *}$ \\
\hline $\begin{array}{l}\text { Selectivity of study programme } e^{*} \text { private sector } \\
\text { (versus public sector) }\end{array}$ & & & & $0.767^{\star *}$ \\
\hline $\begin{array}{l}\text { Specificity of study programme }{ }^{\star} \text { private sector } \\
\text { (versus public sector) }\end{array}$ & & & & -0.021 \\
\hline \multicolumn{5}{|l|}{ Variance components (percentages) } \\
\hline Residual variance level 1: school-leavers & $1.000(72.7)$ & $1.000(74.2)$ & $1.000(72.9)$ & $1.000(72.3)$ \\
\hline $\begin{array}{l}\text { Residual variance level 2: schoolsstudy } \\
\text { programmes }\end{array}$ & $0.001(0.1)$ & $0.004(0.3)$ & $0.000(0.0)$ & $0.001(0.1)$ \\
\hline Residual variance level 3: study programmes & $0.374^{\star *}(27.2)$ & $0.313^{\star *}(23.2)$ & $0.290^{* *}(21.2)$ & $0.276^{* *}(19.9)$ \\
\hline Explained variance & $0.000(0.0)$ & $0.031(2.3)$ & $0.081(5.9)$ & $0.107(7.7)$ \\
\hline Total variance & $1.375(100.0)$ & $1.348(100.0)$ & $1.371(100.0)$ & $1.384(100.0)$ \\
\hline
\end{tabular}

Significance: $* P<0.05 ; * * P<0.01$ (two-tailed).

Source: ROA school-leaver survey 1998.

effect of the specificity of the study programme between the two sectors. So, Hypothesis 5 is not confirmed.

\section{Gross Hourly Wages}

Table 4 gives the results of the wage analysis. Striking is the fact that wages are much more affected by differences between study programmes than (permanent) employment opportunities. From the total variation in wages, 48.0 per cent can be attributed to differences between study programmes (see Model 1). In the analysis regarding (permanent) employment opportunities, these figures were around 27 per cent. Just like the analysis of permanent employment, the wage analysis shows no variation at the level of school-study programme combinations. For the analysis of being employed, the variation at the level of school-study programme combinations was 7.9 per cent. This is larger than the variation in the case of permanent employment and wages, but note that this variation too is not significant. All in all, we conclude that these findings support Hypothesis 1 and partly support Hypothesis 2.

Introduction of the covariates in Model 1 causes hardly any change in the residual variance at the level of school-leavers, but the residual variance at the level of study programmes drops from 48.0 to 44.8 per cent. Overall, this indicates that wage differences are not very strongly related to any of the included variables.

When the three educational characteristics are added in Model 2, the residual variance at the level of study programmes drops sharply from 44.8 to 16.0 per cent. Again, we can note a remarkable difference with the 
Table 4 Results of 3-level analysis of log gross hourly wages: unstandardized regression coefficients $(17,561$ school-leavers within 975 schools*study programmes within 215 study programmes)

\section{Model $0 \quad$ Model $1 \quad$ Model $2 \quad$ Model 3}

\begin{tabular}{|c|c|c|c|c|}
\hline Intercept & $2.207^{\star \star}$ & $2.212^{\star *}$ & $0.837^{\star *}$ & $1.337^{\star *}$ \\
\hline \multicolumn{5}{|l|}{ Level 1 variables } \\
\hline Female (versus male) & & $-0.044^{\star *}$ & $-0.045^{\star *}$ & $-0.047^{\star *}$ \\
\hline Ethnic minority (versus native Dutch) & & 0.022 & 0.023 & 0.020 \\
\hline $\begin{array}{l}\text { First-phase secondary education HAVO } \\
\text { (versus } \mathrm{VBO} / \mathrm{MAVO} \text { ) }\end{array}$ & & $0.012^{*}$ & 0.006 & 0.006 \\
\hline $\begin{array}{l}\text { First-phase secondary education VWO } \\
\text { (versus } \mathrm{VBO} / \mathrm{MAVO} \text { ) }\end{array}$ & & $0.020^{\star *}$ & $0.018^{* *}$ & $0.017^{\star}$ \\
\hline Parental level of education & & $0.003^{* *}$ & $0.003^{* *}$ & $0.003^{* *}$ \\
\hline Private sector (versus public sector) & & & & $-0.680^{\star *}$ \\
\hline \multicolumn{5}{|l|}{ Level 2 variable } \\
\hline Regional unemployment rate & & $-0.006^{\star *}$ & $-0.006^{\star *}$ & $-0.005^{\star *}$ \\
\hline \multicolumn{5}{|l|}{ Level 3 variables } \\
\hline Level of education & & & $0.082^{\star *}$ & $0.055^{\star *}$ \\
\hline Selectivity of study programme & & & -0.006 & -0.011 \\
\hline Specificity of study programme & & & -0.000 & 0.002 \\
\hline \multicolumn{5}{|l|}{ Interactions } \\
\hline $\begin{array}{l}\text { Level of education }{ }^{*} \text { private sector } \\
\text { (versus public sector) }\end{array}$ & & & & $0.036^{\star *}$ \\
\hline $\begin{array}{l}\text { Selectivity of study programme }{ }^{*} \text { private sector } \\
\text { (versus public sector) }\end{array}$ & & & & $0.067^{\star \star}$ \\
\hline $\begin{array}{l}\text { Specificity of study programme }{ }^{\star} \text { private sector } \\
\text { (versus public sector) }\end{array}$ & & & & $-0.003^{\star *}$ \\
\hline \multicolumn{5}{|l|}{ Variance components (percentages) } \\
\hline Residual variance level 1: school-leavers & $0.065^{\star \star}(52.0)$ & $0.064^{* \star}(51.2)$ & $0.064^{\star *}(51.2)$ & $0.064^{\star *}(51.2)$ \\
\hline $\begin{array}{l}\text { Residual variance level 2: schoolsstudy } \\
\text { programmes }\end{array}$ & $0.000(0.0)$ & $0.000(0.0)$ & $0.000(0.0)$ & $0.000(0.0)$ \\
\hline Residual variance level 3: study programmes & $0.060^{\star *}(48.0)$ & $0.056^{\star \star}(44.8)$ & $0.020^{* *}(16.0)$ & $0.018^{\star *}(14.4)$ \\
\hline Explained variance & $0.000(0.0)$ & $0.005(4.0)$ & $0.041(32.8)$ & $0.043(34.4)$ \\
\hline Total variance & $0.125(0.0)$ & $0.125(100.0)$ & $0.125(100.0)$ & $0.125(100.0)$ \\
\hline
\end{tabular}

Significance: $* P<0.05 ; * * P<0.01$ (two-tailed).

Source: ROA school-leaver survey 1998.

analysis of (permanent) employment opportunities, where the reduction in the residual variance was much smaller. The only significant effect on wages is from the level of education. Each additional year of schooling increases the wage level by 9 per cent $\left(\mathrm{e}^{0.082}=1.085\right)$.

In Model 3, the effects of the three educational characteristics are once again estimated separately for the private and the public sector. In this model, the residual variance at the level of study programmes is 14.4 per cent. The results reveal that all three interactions are significant. First of all, the effect of level of education is present in both the public and the private sector-which supports Hypothesis 3-, although the effect is larger in the latter sector $(0.055+0.036=0.091)$. Second, and contrary to Hypothesis 4, the impact of the selectivity of the study programme is larger in the private sector than in the public sector. Third, the effect of the specificity of the study programme is smaller in the private sector than in the public sector-which is in contrast to Hypothesis 5-, although in both sectors the effect is not statistically deviating from the value zero.

\section{Conclusions and Discussion}

The empirical evidence presented in this article demonstrates that labour market research typically underestimates the total effect of education, because it does not take into account unmeasured characteristics of education. This underestimation (that is, the residual variance at the level of study programmes and school-study programme combinations) is 29 per cent in the analysis 
of being employed, 20 per cent in the analysis of being permanently employed and 14 per cent in the analysis of gross hourly wages. We have to keep in mind, however, that the underestimation in the case of the effects of education on (permanent) employment opportunities may be exaggerated. The comparison between the estimated multilevel models may be problematic, as the explained variance in a logistic multilevel analysis (that is, in the analysis of (permanent) employment) is considerably smaller than in a multilevel analysis with a metric dependent variable (that is, in the wage analysis) (Snijders and Bosker, 1999:226).

Overestimation, on the other hand, does not seem to present a major problem: after controlling for differential selection of students in study programmes and the location of schools in regions with different labour market conditions, the effects of education decrease only slightly. Once again, we need to be careful when comparing the explained variances of binary and metric-dependent variables. Moreover, we should be aware that these results reflect a minimum degree of overestimation, as only a restricted number of covariates has been included. ${ }^{6}$ On the other hand, it is unlikely that introduction of other relevant characteristics will change the findings drastically: the model already contains some of the most important predictors and even these do not affect the estimation of the net effects of education very much.

The estimation of the total net effect of education varies widely between the different socio-economic outcomes under investigation. Almost one-half of the variation in wages is related to education. In the case of employment opportunities this effect is substantially lower: around one-third of the variation in the likelihood of being employed is associated with education. In the case of permanent employment opportunities, the total net effect of education is about one-quarter of the variation. Put differently, wages are to a larger extent determined by educational credentials than (permanent) employment opportunities, while the latter are more affected by individual differences.

In the Netherlands, schools do not matter significantly when decomposing the effects of education into differences between study programmes and differences between schools. Less than 1 per cent of the total variation in the likelihood of having a permanent job and wages can be attributed to differences between schools. These small school effects are in line with the highly standardized education system in the Netherlands, where differences in school quality are, generally speaking, rather modest. However, schools do make some difference in helping their school-leavers to actually find a job: 9 per cent of the variation in the likelihood of being employed can be attributed to the specific school that was attended. Note that this school effect was found after controlling for regional differences in the labour market situation. It probably relates to activities such as career counselling or differences between schools in establishing networks with prospective employers.

For the most part, the effects of education on socioeconomic outcomes reflect differences in study programmes. It is likely that this result is related to the high level of stratification in the Dutch education system. Level of education turned out to have the most profound effects. High-educated school-leavers more often have a permanent job and earn more than low-educated school-leavers. In fact, these results echo previous research on the impact of level of education on socio-economic outcomes. In addition, the selectivity of the study programme shows an interesting effect. Having followed a study programme that is highly selective on entry has a positive effect on the likelihood of being employed. Since we controlled for the school-leaver's entry level of education (that is, the level of first-phase secondary education), this selectivity effect is a study programme effect rather than an individual effect. Finally, we found that-contrasting our hypotheses-the effect of level of education and the selectivity of the study programme on the likelihood of permanent employment and wages are larger in the private than in the public sector, whereas the reverse is true for the effect of the specificity of the study programme on wages.

It is clear that these results cannot simply be explained in terms of the theoretical arguments we have outlined. The absence of an effect of level of education on the likelihood of being employed could point in the direction of human capital theory, but this is contradicted by the fact that we found a positive effect of the selectivity of the study programme on job chances, which is more associated with job competition theory. Moreover, we hypothesized that selection processes in the private sector with its openemployment positions follow a human capital model with strong effects of level of education and specificity, while in the public sector with its emphasis on credentials, level of education and selectivity would be the dominant factors. This is less puzzling if we take some other structural and institutional factors into account. First of all, (youth) unemployment in the Netherlands in the late 1990s was extremely low. This means that higher-educated school-leavers did not have to compete with lowereducated ones for the same jobs. Within each segment, 
however, employers still favoured those from the more selective study programmes, as is illustrated by the positive effect of selectivity. A second factor is the more institutionalized wage-setting mechanism in the public sector. As a result, the overall wage inequality is much smaller in the public sector than in the private sector. The same applies to other terms of employment. Permanent employment opportunities are larger in the public sector than in the private one. Especially the lower educated and those coming from less-selective study programmes profited from this. Also the positive effect of specificity in the public sector points to an absence of market mechanisms in professionalized segments such as health care, where job access is controlled by the professional elite. In the private sector, however, where open-employment relationships force employers to look for job applicants with the highest expected productivity, level of education and selectivity have profound effects on wages and permanent employment opportunities.

The results of this article lead to three possible extensions for future research. First, we should improve upon the measures used for the different components of the training costs model. The measure of the specificity of the study programme is strictly speaking not equivalent to the relative degree to which the study programme in question provides the required skills. Nor does the measure of selectivity fully grasp the risk that students will pass the exam without having a minimum level of skills. Even in the case of the third component, the effort that employers have to make to 'bridge' any existing skill deficiencies, one may question whether level of education is a sufficient measure. We expect that improvements in these measures will lead to a better explanation of the effects of education.

Second, the results indicate that apart from educational characteristics, structural and institutional factors shape the school-to-work transition. Changes in the opportunity structure may interact with the effects of the educational characteristics. Moreover, institutional factors may obscure the 'normal' effects of education, leading to either stronger or weaker effects than theoretically predicted. Although taking into account regional unemployment rates and distinguishing between the private and the public sector has already shed some light on the role of these factors, it is clear that we should elaborate our models much more in this direction.

Third, the results refer to a population of schoolleavers from one single country. The question is to what extent the results can be generalized to the whole Dutch population or to other countries than the Netherlands.
Following signalling theory (Spence, 1973), we may expect that educational credentials are especially relevant during the transition from school to work and that individual traits become more important in determining the further career. This means that the effects of education are largest among the group of school-leavers and that the total effect of education decreases over the life course. In that sense, one could argue that the effects of education found here provide an upper limit of the total effect of education. But the relative importance of the different training costs components may change as well. Having followed a study programme that specifically prepares for certain occupations, may provide school-leavers an entrance ticket to the labour market, but may also in the longterm have a negative effect when technological developments change the skills requirements and make the existing skills obsolete. Moreover, specificity may have a negative effect on the flexibility of school-leavers to take other jobs, not related to their study programme. This may especially become relevant in the long-run. It is important, therefore, to investigate the long-term effects of education as well. Moreover, it would be interesting to see to what extent similar results can be found in other countries. As we indicated earlier, the Dutch education system can be characterized as highly standardized and highly stratified. This is probably the reason why schools matter so little in the Netherlands and why study programmes matter so much. Does this imply that in countries where the education system is less standardized and stratified, such as in the USA, we will find much more variation between schools or colleges and less so between study programmes? And what about the relative importance of the different training costs components? It is likely that in countries characterized by occupational labour markets, the relative degree to which a specific programme provides the required skills is more important than in countries where internal labour markets prevail (Gangl, 2001). And conversely, the other two components will probably prevail in countries with a strong emphasis on internal labour markets. Therefore, we aim at extending our research to other countries, in order to explore the validity of this expected cross-national variation in outcomes.

\section{Notes}

1. In some sense, the term 'total' effect of education may be misleading, since the lowest educated school-leavers are not analysed in this article. Nevertheless, we think that it is possible to speak 
about the total effect of education without having the total variation in education. In fact, the restricted sample will result in a conservative estimation of the total effect of education.

2. Credential theory (Collins, 1979) goes even further by arguing that elites use educational credentials to control the access to high-level status groups. As Bills (2003) points out, the credential view opposes human capital theory as well as job competition theory in the sense that it basically challenges the relationship between education and labour productivity. In the absence of any direct assessment of the actual skills of workers on the one hand and their productivity on the other, there is no way to empirically settle this issue. Therefore, we focus in this article only on the human capital and job competition theory.

3. The operationalization of open- versus closedemployment relationships as private versus public sector is not ideal, because there is also a class dimension involved (closed positions are typical for jobs in the salariat even within the private sector) and open positions are presumably only present when there is free market competition (which is likely to be only in a few segments of the Dutch economy due to minimum-wage regulations).

4. Based on another data set (VOCL'89), we calculated the correlation between the choice of the level of first-phase secondary education and the final level of educational attainment (measured as years of schooling) at 0.50. Moreover, multivariate analysis on the same data set showed that among a great number of independent variables (like parental socio-economic status, parental level of education, ethnicity, IQ, student's scores on nationally standardized tests on Dutch language, arithmetic, and information processing at age 12), the advice given by the primary school teacher concerning the level of first-phase secondary education (which coincides largely with the actual choice of first-phase secondary education) is by far the best predictor of the final level of education attained (Traag et al., 2004).

5. It is questionable whether sector is exogeneous to permanent employment. However, our prime interest is not in the main effect of sector. Rather, we are interested in the interaction effects between sector and the measured educational characteristics to distinguish between human capital and job competition explanations of effects of education.

6. Most surprising is the finding that the effect of the level of first-phase secondary education is barely noticeable, despite the fact that it is strongly correlated with the final level of education (see Note 4). Maybe this is because the sample excludes the least qualified, leading to restricted variation in cognitive ability between students when entering the different study programmes in upper secondary and tertiary education. It may also be that we used a poor measure of the level of first-phase secondary education in the sense that selection into study programmes on the basis of ability (or some similar unobserved variable) is badly represented by this variable.

\section{References}

Becker, G. S. (1964). Human Capital. A Theoretical and Empirical Analysis, with Special Reference to Education. New York: NBER.

Bills, D. (2003). Credentials, signals and screens: explaining the relationship between schooling and job assignment. Review of Educational Research, 73, 441-470.

Bishop, J. (1989). Occupational training in high school: when does it pay off?. Economics of Education Review, 8, 1-15.

Bosker, R. J., van der Velden, R. K. W. and van de Loo, P. (2001). Assessing Institutional Effects of Colleges. The Labour Market Success of Their Graduates. In Nieuwenhuis, L. F. M. and Nijhof, W. J. (Eds.), (2001). The Dynamics of VET and HRD Systems. Enschede: Twente University Press, pp. 153-168.

CBS (2002). Beroepsbevolking; Naar Regio Vanaf 1991, available from <http://statline.cbs.nl> [accessed 16 January 2002].

Collins, R. (1979). The Credential Society: An Historical Sociology of Education and Stratification. New York: Academic Press.

Dolton, P. and Vignoles, A. (2000). The effects of school quality on pupil outcomes: an overview. In Heijke, H. and Muijsken, J. (Eds.), (2000). Education, Training and Employment in the Knowledge Based Society. Houndmills/London/ New York: Macmillan, pp. 91-116.

Gangl, M. (2001). European patterns of labour market entry: a dichotomy of occupationalized versus non-occupationalized systems? European Societies, 3, 471-494. 
Glebbeek, A. (1988). De arbeidsmarktpositie van opleidingen. Ontwikkeling en illustratie van een theoretisch model. Tijdschrift voor Arbeidsvraagstukken, 4, 75-89.

de Graaf, P. M. and Wolbers, M. H. J. (2003). The effects of social background, sex, and ability on the transition to tertiary education in the Netherlands. The Netherlands' Journal of Social Sciences, 39, 172-201.

Huijgen, T. and Wolbers, M. H. J. (1999). Methodiek schoolverlatersinformatiesysteem 1998. Maastricht: ROA.

Kerckhoff, A. C., Raudenbush, S. W. and Glennie, E. (2001). Education, cognitive skills and labor force outcomes. Sociology of Education, 74, 1-24.

Mortimore, P., Sammons, P., Stoll, L., Lewis, D. and Ecob, R. (1988). School Matters: The Junior Years. Wells: Open Books.

Mülller, W. and Gangl, M. (Eds.) (2003). Transitions from Education to Work in Europe. The Integration of Youth into EU Labour Markets. Oxford: Oxford University Press.

Rosenbaum, J. E., Kariya, T., Settersten, R. and Maier, T. (1990). Market and network theories of the transition from high school to work. Their application to industrialized societies. Annual Review of Sociology, 16, 263-299.

Rosenbaum, J. E., DeLuca, S., Miller, S. R. and Roy, K. (1999). Pathways to work: short- and long-term effects of personal and institutional ties. Sociology of Education, 72, 179-196.

Scheerens, J. and Bosker, R. J. (1997). The foundations of educational effectiveness. Oxford: Pergamon.

Shavit, Y. and Müller, W. (Eds.) (1998). From School to Work. A Comparative Study of Educational Qualifications and Occupational Destinations. Oxford: Clarendon Press.

Snijders, T. and Bosker, R. J. (1999). Multilevel Analysis. An Introduction to Basic and Advanced Multilevel Modeling. London/Thousand Oaks/New Delhi: Sage.

Sørensen, A. B. (1983). Processes of allocation to open and closed positions in social structure. Zeitschrift für Soziologie, 12, 203-224.
Spence, M. (1973). Job market signalling. Quarterly Journal of Economics, 87, 355-374.

Traag, T., van der Valk, J., van der Velden, R., de Vries, R. and Wolbers, M. (2004). Leren Loont! De overgang van school naar werk voor leerlingen van het VOCL'89. Maastricht: ROA/CBS.

Thurow, L. C. (1975). Generating Inequality. New York: Basic Books.

van der Velden, R. K. W. and van Smoorenburg, M. S. M. (1999). Overscholing en Beloning: Het Effect van Verschillende Meetmethoden. Tijdschrift voor Arbeidsvraagstukken, 15, 111-123.

van der Velden, R.K.W. (2001). Educational Systems and the School-to-Work Transition. A Conceptual Framework. Paper for the Network Transitions in Youth 2001 workshop in Sintra, Portugal.

van de Werfhorst, H. and Kraaykamp, G. (2001). Four field-related educational resources and their impact on labor, consumption, and sociopoliticial orientation. Sociology of Education, 74, 296-317.

Wilson, K. L. and Smith-Lovin, L. (1983). Scaling the prestige, authority, and income potential of college curricula. Social Science Research, 12, 159-186.

\section{Authors' Addressess}

Rolf K.W. van der Velden (to whom correspondence should be addressed), Research Centre for Education and the Labour Market (ROA), Maastricht University, P.O. Box 616, 6200 MD Maastricht, The Netherlands. Email: r.vandervelden@roa.unimaas.nl.

Maarten H.J. Wolbers, Department of Social Research Methodology, Faculty of Social Sciences, Free University Amsterdam, De Boelelaan 1081, 1081 HV Amsterdam, The Netherlands. Email: mhj.wolbers@fsw.vu.nl.

Manuscript received: June 2005. 